\title{
MORTEN NIELSEN
}

\section{FOR EN OPLØSNING AF ALLE SELVFØLGELIGHEDER \\ Et teoretisk bidrag til den kritiske analyse}

\author{
Folk ved, hvad de gør; \\ ofte ved de, hvorfor de gør, hvad de gør; \\ men hvad de ikke ved er, hvad det, de gør, gør. \\ (Michel Foucault)
}

Mit forehavende med denne artikel er at bidrage til den praktiske udøvelse af kritisk antropologi. I udgangspunktet læner jeg mig op af Nietzsches forståelse af kritik. Nietzsche stiller spørgsmålstegn ved bestående værdier $u d$ fra deres vardi for efterfølgende at vurdere, om disse reelt virker befordrende for vores eksistens (1999 [1887]:17). Michel Foucault har senere videreført denne tanke i hans analyser af de selvfølgeligheder vore praksisser hviler på (Mahon 1992:104). Her er intentionen at forårsage ideologiske sammenbrud, ,således at handlinger, gestusser, diskurser som hidtil har været implicitte forståelser bliver problematiske, svære, farlige“ (Foucault 1991:84).

Indledningsvis vil jeg gerne pointere, at jeg ikke mener, at nogen antropologisk genre har privilegeret status som værende særlig kritisk. Den nietzscheanske samfundskritik har bestandigt været et aspekt af antropologien, der imidlertid bliver mere eller mindre betonet afhængigt af forfatteren og den samtid, hvori denne udfærdiger sine tanker. Når jeg derfor taler om en kritisk antropologi, er det udelukkende for at rette fokus imod de fortolkningsniveauer, der muligg ør en spørgen til bestående værdier „ud fra deres værdi“.

I det følgende præsenterer jeg en teoretisk tilgang til kritisk analyse baseret på Foucaults sene værker, som jeg forholder til empiri fra eget feltarbejde i Nordøst-brasilien. Denne empiri tjener altså i denne omgang udelukkende som eksemplificerende baggrund for en teoretisk diskussion. Det er samtidig nødvendigt at understrege, at det teoriapparat, jeg her præsenterer ikke kan eller skal stå alene i et egentligt analyse-arbejde. Snarere skal det ses som et bidrag til bredere kritikker af sociale, økonomiske og kulturelle forhold. ${ }^{1}$

\section{Optakt til en kritik}

George Marcus beskriver andetsteds i nærværende tidsskrift den identitetskrise, som an-tropologien har gennemløbet igennem de sidste 15 år. Det er Marcus’ opfattelse, at faget siden 1980'ernes postmodernistiske selvkritik gradvist har tabt terræn; dels har 
antropologien i stigende grad inkorporeret andre fagområders termer uden at reflektere over det derved implicitte betydningsskred, dels er den praktiske involvering i verden uden for de akademiske mure begrænset. En vej ud af denne blindgyde er en genfortolkning af det metodiske projekt, hvorved der stilles spørgsmålstegn ved de ,magt/ vidensmaskiner”, der fratager faget sit autonome virkerum. Marcus mener, at de antagelser, der for eksempel etableres på baggrund af feltarbejde inden for „,det økonomiske system“, tager eksistensen af systemet for givet. I stedet bør man unders $\varnothing g e$ $\varnothing$ konomien etnografisk og integrere denne analyse i en ,multisited ethnography”. Dette er netop konsekvensen af, at økonomien ikke er en ahistorisk idealfigur, men snarere et konventionelt etnografisk objekt, hvis eksistens må underkastes etnografiske studier; økonomiens selvfølgelighed må altså opløses. Idéen om „,multisited ethnography“ skal ses som et udslag af studie-objektets ændrede udformning (Marcus 1998). De kulturelle formationer, vi tidligere har kunnet analysere i ,single sites“, er nemlig ikke lokale i deres karakter. Derfor må antropologen ændre sin tilgang til og definition af konteksten, hvis han vil have en grundlæggende forståelse for formationernes struktur. Antropologien kan derved genfinde tabt styrke igennem en metodisk og analytisk omkalfatring af de kontekster, der ofte forudsættes snarere end analyseres. I eftersporingen af studieobjektet igennem forskellige lokaliteter aftegner der sig nemlig tværgående mønstre, hvilket presser antropologen til at genoverveje de selvfølgeligheder, der uvægerligt sniger sig ind i det analytiske arbejde.

Spørgsmålet om de brede strukturer optager også John Liep, der i „Markedet i vores hoveder" (1999) forsøger at genindsætte spørgsmål om magtforhold og økonomiske strukturer i det antropologiske projekt. Det handler for Liep om at komme udover det postmoderne dilemma for igen at kunne problematisere de generelle politiske og sociale spørgsmål, der optager vores samtid. Det, der kræves, er en kritisk forståelse af de betingelser, der opretholder kulturel kontinuitet og fællesskaber (op.cit.:65). I stedet for at anskue „kultur“ og „,samfund“ som homogene konstanter, kan vi se dem som projekter om fællesskab. Derved underkastes fællesskaberne kritisk analyse, der belyser de magtforhold og strukturer, som de indgår i.

Hvis man kondenserer og sammenfører de to forfatteres argumenter, er det muligt at fremlæse en fælles tilgang til antropologien, der vil videre end det postmoderne scenario uden dog at miste en kritisk holdning til den omverden, vi søger at begribe. Både Marcus og Liep udtrykker $\emptyset$ nske om i højere grad at udsætte konteksten for vores studier for analytisk kritik. I denne artikel vil jeg netop forsøge at møde forfatternes ønske. Problemet er blot, hvordan dette arbejde skal gribes an. Jeg er nemlig ikke enig med Marcus i, at „,multisited ethnography“ er den vej, vi nødvendigvis må gå for at resituere antropologien og derved genvinde tabt terræn. Ved at følge studieobjektet rundt i forskellige lokaliteter aftegnes ganske rigtigt nye mønstre, der omstrukturerer tænkningen om feltet, men dette vil ikke a priori opløse kontekstens selvfølgeligheder. Marcus' intention er at afdække studieobjektets karakter, og som følge heraf kontekstens multidimensionelle struktur. Spørgsmålet er blot hvilken viden, der udvindes af dette analytiske arbejde. Her hævder Marcus, at det afgørende spørgsmål er den „systemviden“, der eksisterer i aktørernes hverdagsbevidsthed og handlinger (Marcus 1998:96), altså i hvor høj grad aktøren er sig bevidst om de (magt)relationer og strukturer, som denne er indlejret i. Men er dette ikke at stoppe lige før målet? Marcus' metodiske forslag genererer ganske rigtigt en forståelse for kontekstens fragmenterede strukturer, men jeg er skeptisk over for om 
de spørgsmål, som Marcus anser som primære, også kan opløse de selvfølgeligheder, vi konfronteres med. Skal Marcus' spørgsmål ikke suppleres med andre og vigtigere, såsom: Hvordan præger den fremanalyserede kontekst aktørens handlinger? Hvilke dynamikker er indeholdt i den kontekst, hvis selvfølgeligheder vi ønsker at opløse? Og slutteligt: Igennem hvilke kulturelle og sociale processer er disse selvfølgeligheder blevet konstitueret, således at de kan fremstå netop som selvfølgeligheder? Her er Lieps problemstilling relevant. Det er nødvendigt igen at se på magtstrukturer og de praktiske udformninger, som disse antager. Men dette kan ikke gøres ved en simpel genopdagelse af de ,,institutioner og grundlæggende kulturelle værdier”, som i de sidste 20 år har været dekonstruktivismens primære skydeskiver (Laclau \& Mouffe 1985:113; Derrida 1978). Postmodernismen har ikke været forgæves. Vi står således med et problemkompleks, hvis realitet er uomgængelig, men hvis løsning stadig lader vente på sig.

I det følgende vil jeg derfor skitsere en tilgang, der i beslægtede fagområder har vist sig særdeles nyttig i kritiske studier af de empiriske analysers bredere sociale, kulturelle og politiske kontekster (Crossley 1994; Shields 1991; Tamboukou 1997). Udgangspunktet er at begribe den sociale samhørighed, som den tager form, hvor social samhørighed skal forstås som en foreløbig og skrøbelig overenskomst, der konstant videreudvikles (Raffnsøe 2002:17). Den er skrøbelig, idet vi ikke er forbundet i ét substantielt fællesskab, der danner et sikkert fundament for den sociale udveksling. Snarere synes de sociale bånd, der binder os sammen, at bestå af en række gensidigt overlappende tråde, hvoraf ingen, isoleret betragtet, fremstår som substantielle og grundlæggende. I deres samvirke danner disse tråde alligevel et komplekst netværk, som til stadighed virker bestemmende på de enkelte sociale handlinger. Sammenhængskraften er dog aldrig større, end at overenskomsten bestandigt bestrides og synes at være på vej imod opløsning. Udgangspunktet for denne analyseform er Michel Foucaults begreb dispositiv (dispositif), der indledningsvist kan defineres som en regularitet eller sammenhæng mellem hændelser, der former social omgang (Foucault 1991:75; Raffnsøe 2000:66). Jeg åbner for denne diskussion igennem en beskrivelse af empiri fra eget feltarbejde. Herefter redegører jeg for de teoretiske aspekter af en dispositionel analyse, der efterfølgende virker som optik for en genlæsning af mit empiriske materiale. Sluttelig diskuterer jeg den præsenterede tilgang i forhold til antropologisk teori og hævder, at Foucaults iagttagelser med nytte kan danne basis for kritisk antropologisk tænkning.

\section{Empirisk adgang}

Ganske som de fleste andre specialeskrivende er jeg gentagne gange stødt på problemer, der i øjeblikket virkede uoverstigelige; enten rent empiriske problemstillinger, hvor de forskellige fragmenter af virkeligheden set i sammenhæng absolut ingen mening gav, eller teoretiske knuder, der, som læsningen skred frem, fikserede mit materiale på en sådan måde, at det analytiske arbejde blev ren deduktion. Jeg skal her blot redegøre for den mest centrale problemstilling, der resulterede i en mere grundlæggende kritisk læsning af mit empiriske materiale.

Fra januar til august 2001 udførte jeg feltarbejde i Recife, hovedstad i den brasilianske delstat Pernambuco, beliggende i den nordøstlige og fattigste del af landet. Som det er tilfældet i de fleste andre brasilianske storbyer, er også Recifes urbane situation præget af et stadig stigende antal illegale bosættelser, favelas. Den til stadighed mang- 
lende politiske vilje til at løse favela-problemet på en effektiv måde har resulteret i, at mere end halvdelens af Recifes 1,6 mil. indbyggere i dag bebor jord, der tidligere tilhørte enten kommunen eller private ejere (Souza 2001:483). De ca. 500 bosættelser, der kan betegnes favelas, udgør i de forskellige kvarterer den absolutte periferi. Denne position forstærkes yderligere af en ubehersket ejendomsspekulation, der fratager fattige grupper enhver mulighed for at erhverve sig jord på legal vis.

Jeg studerede politisk lederskab i Milagres, en centralt beliggende favela i Recife. De fleste illegale bosættelser, der har eksisteret i mere end 10-15 år, har en lille „elite“ af lokale ledere, der varetager områdets politiske interesser, hvilket generelt inkluderer to ideelle mål: opnåelse af jordejerskab og forbedring af de infrastrukturelle forhold. Allerede under Getúlio Vargas' populistiske styre (1930-1945) havde ledere i de fattigste områder en begrænset politisk betydning. Vargas var den første præsident, der direkte forankrede sit styre i arbejderklassens støtte snarere end i elitens og middelklassens (Huchzermeyer 2002:87). Dette ændrede dog ikke ved favela-beboernes marginaliserede position, idet dyadiske patron-klient-forhold mellem lokalpolitikere og favela-ledere i stigende grad karakteriserede mulighedsrummet for politiske og sociale forbedringer. På denne måde er illegale bosættere forblevet i den politiske periferi. I stedet for horisontale anknytninger, der kunne forene favela-beboere i deres kamp for forbedrede rettigheder, har tendensen været vertikale personlige relationer med fokus på ,at skaffe mest muligt til fællesskabet" (trazer o melhor pra a comunidade). Genivaldo, en tidligere leder af Miliagres' primære beboerforening, beskriver dette forhold:

Jeg: Og dette arbejde, som du lavede for den der politiker, hvilken type arbejde var det? Genivaldo: Hør her, jeg arbejdede for en politiker i det øjeblik, han lavede en aftale om at forbedre [forholdene] og skaffe mest muligt til området Miliagres, ikke? Så jeg støttede kun den politiker, som skaffede mest muligt til dem, der behøvede det.

Jeg: Og disse politikere tilbød fællesskabet ting?

Genivaldo: De støttede fællesskabet, gjorde det muligt at fortsætte med markedet, med vuggestuen [...] Min ideologi var at arbejde og skaffe mest muligt til fællesskabet uafhængigt af det politiske parti. Det var ligegyldigt, hvem der styrede, om de var fra venstre eller højre eller andre fraktioner. Hvad der interesserede mig var, at de skaffede noget. Ham, der skaffede noget, var min politiker. Hvis han behøvede mig, var jeg ved hans side, ikke? Jeg arbejdede altid sådan.

Jeg: Så hvis vi forestiller os, at João Paulo [borgmesteren i Recife] i morgen siger til dig: ... Genivaldo: (afbryder) Så kan han blive min kandidat.

Jeg: Hvis han ...

Genivaldo: (afbryder) ... støttede fællesskabet Miliagres, så ville jeg være ved hans side.

\section{Introduktionen af „deltagelse“ som politisk redskab}

Igennem de seneste 15 år er der dog flere faktorer, der indikerer, at dette forhold er i færd med at blive omstruktureret. I 1987 blev PREZEIS ${ }^{2}$ etableret, der virker både som et lovkompleks og som et projekt. PREZEIS-loven har givet 66 invaderede områder status af ZEIS, ${ }^{3}$ hvilket beskytter beboerne imod forflytning og forhindrer jordspekulation (FASE 1997:5). Loven etablerede en legal mekanisme, der giver beboerne ret til jordbesiddelse uden ejerskab (Assies 1991:265). Derudover blev det fastsat, at prioriteringer for områdernes urbane forbedringspolitik skal fastlægges gennem dialog med 
bosætterne (Wampler 2000:8). Der sker altså en forskydning af den politiske betydning, der tillægges denne gruppe, fra en position som illegale bosættere til at være reelle deltagere i det politiske arbejde. For at kunne implementere disse juridiske tiltag i praksis, er PREZEIS-projektet gradvist blevet etableret som et integreret samarbejde mellem favela-lederne i et tæt samarbejde med offentligt ansatte og ngo-arbejdere.

Sideløbende med PREZEIS er et langt mere omfattende projekt, ,Orçamento Participativo“ (Participatorisk Økonomisk Planlægning), blevet realiseret. Ved et offentligt møde netop om „Orçamento Participativo“ holdt João Costa, den officielle koordinator, en indledende brandtale:

\begin{abstract}
Vores borgmester João Paulo har afgivet et løfte om, at befolkningen skal have mulighed for at deltage. Her er det grundlæggende instrument 'Orçamento Participativo', er alle klar over det? 'Orçamento Participativo' er iværksættelse af flere ting: Det er at udregne byens budget, at udregne hvor mange penge, man har. Når man får løn, kan man overveje, hvad de penge skal bruges til. Det er at lave budget [orçamento]. Byen ser på hvilke penge, den har, og hvad de skal bruges til. Alle spørger sig selv om dette, også byen: Skal vi lave en bro eller en kanal? Skal vi bruge pengene på skoler eller karneval? Nu beder byen Jer om at deltage.
\end{abstract}

Ved et andet møde etableret for at informere folk yderligere om „Orçamento Participativo“, fremlagde en offentlig medarbejder den grundlæggende ideologi:

Bystyret erkender, at deltagelse er afgørende. [...] Vi søger transparente relationer til bydistrikterne. [...] Idéen er at gøre $100 \%$ af kommunens budget transparent. Vi vil sikre klarhed [...] Vi vil skabe et alternativ til en stat styret af markedet.

„Orçamento Participativo“ er det foreløbige slutresultat af en proces, der indledtes i dik-taturets sidste fase. Grundet en stigende utilfredshed med de resultater, oppositionen havde opnået, besluttede mange fagforeningsledere at danne et nyt parti (Abers 2000:47). Da den længe ventede reform, der tillod etablering af nye partier i 1980, blev vedtaget, dannedes derfor „Partido dos Trabalhadores“ (PT) (Arbejderpartiet). PT arbejdede for en ,bottom-up“-struktur baseret på folkelig deltagelse. Ideologien var svag, men partiet havde to prioriteter: Inversão de prioridades (omvending af prioriteter) og participação popular (folkelig deltagelse). Samlet skulle disse elementer føre til de autoritære traditioners endeligt samt integrere de „hidtil ekskluderede“ (Stiefel \& Wolfe 1994:6) i de politiske beslutningsprocesser. For at omsætte disse prioriteter til virkelighed skabte PT „Orçamento Participativo“, der siden hen er blevet partiets politiske flagskib. Gennem møder i alle kvarterer i byen får beboere mulighed for at vælge prioriteter til budgettet; altså kloakering, uddannelse, kulturelle aktiviteter, etc. De prioriteter, der til disse møder får flest stemmer, inkorporeres i næste års budgetforslag.

Etableringen af „Orçamento Participativo“ og politiseringen af de illegale bosættelser under PREZEIS er to processer, der igennem de sidste tyve år er forl øbet sidel $\varnothing$ bende. Anskues de i sammenhæng, er der angiveligt én betydningstæt kerne, der underordner alle andre elementer, nemlig deltagelse. Både PREZEIS og „Orçamento Participativo“ sætter som præmis for deres aktiviteter en høj grad af deltagelse iblandt de grupper, projekterne berører. For PREZEIS gælder dette beboerne i de særligt udvalgte illegale bosættelser, mens det for „Orçamento Participativo“ vedrører byens samlede befolkning. Hvis vi opstiller denne logik over for beskrivelsen af favela-ledernes hidtidige praksis, er 
der et åbenlyst brud i måden, hvorpå politisk handling begribes. Favela-ledere har igennem årtier baseret deres praksis på personlige relationer til lokalpolitikere, hvor beboerne i områderne blev tildelt både personlige og kollektive goder afhængig af relationens karakter og styrke. Dette forhold hævder både PREZEIS og „Orçamento Participativo“ at eliminere ved at betone beboernes direkte deltagelse. Det er en normativ forskydning, hvor deltagelse går fra at være irrelevant til at være et kriterium for, at man som beboer kan stille politiske krav.

\section{Problematisering af det analytiske arbejde}

Dette forhold genererede flere problemer for mit analytiske arbejde: Hvordan er det muligt at forklare dette skift uden at tale om radikale brud? Hvordan kan en ny normativitet forklares uden at essentialisere den; uden at gøre den til en ,grundlæggende kulturel værdi“ (Liep 1999:65)? Konteksten for mit feltarbejde var ikke præget af en entydig accept af den ny logik. De fleste ledere forholdt sig ekstremt forbeholdne over for kravet om folkelig deltagelse. Dette kan dog forklares ved at henvise til den patron-klient-praksis, de hidtil har praktiseret. Elimineres den vil også en fast indtægt som indsamler af stemmer for lokalpolitikerne forsvinde. Hvad der dog som udenforstående - og allerede moralsk situeret betragter - undrede mig, var holdningen blandt både ledere og beboere til de participatoriske tiltag. I min naive forudindtagethed anså jeg nemlig disse politikker som „goder“ i sig selv. De beboere, jeg talte med, var udmærket klar over deres manglende muligheder for politisk indflydelse. Alligevel var mange skeptiske over for de nye politiske tiltag som PREZEIS og „Orçamento Participativo“, trods det forøgede politiske mulighedsrum disse etablerede. Konteksten for mit feltarbejde var altså præget af en tvetydighed i forholdet til de politiske processer, der var i gang med at transformere mine informanters virkelighed. Ikke desto mindre virkede det uomgængeligt, at radikale ændringer var i gang med at ske. Det, jeg således manglede i mit arbejde, var et analytisk vokabular, der kunne hjælpe til at forklare, hvordan normative logikker forandres, påvirker og udspringer af handling uden at essentialisere disse. Altså et kritisk redskab i forståelsen af de implicitte magtforhold, der virker medbestemmende på udformningen af individets handlingsrum. Med udgangspunkt i Foucaults begreb dispositif præsenterer jeg i det følgende en sådan tilgang.

\section{Dispositivet}

Foucaults anliggende er at redegøre for, hvordan selvfølgeligheder kan opleves som grundlæggende erfaringer. Det er således mulighedsbetingelserne for, at de kan fremstå, „sådan som det faktisk er", der bliver fremskrevet igennem hele forfatterskabet. Denne redegørelse fordrer en afdækning af den pågældende selvfølgeligheds konstitutions-historie, der kan vise, hvorledes selvfølgeligheden er blevet til igennem en række sociale praksisser (Raffnsøe 2002:63 ff.). Den logik, der her fremskrives, synes altid allerede at være „usamtidig“ i forhold til den samtid, hvori den virker. At den kan tematiseres indebærer nemlig en forudsat fremtid, der vil gøre selvfølgeligheden mulig, men som allerede er forskudt i forhold til erfaringens konstitutionshistorie. Foucault etablerer altså 
en relation mellem den enkelte begivenhed og det, den efterfølgende giver anledning til. Han søger at gribe den sociale omgang, idet den begynder at tage form og tegne bestemte linjer. Det niveau, der her skitseres, er dispositivets:

Bag et sådant navn [dispositivet] søger jeg at pejle mig frem til et afgjort heterogent hele eller sammenspil. Det indeholder diskurser, institutioner, arkitekturindretninger, regu-lative beslutninger, love, administrative forholdsregler, videnskabelige ytringer, filosofiske, moralske, filantropiske forslag og påstande. Det udsagte, såvel som det ikke udtalte, er, kort sagt, dele af dispositivet. Dispositivet selv er det net af forbindelseslinjer, som man kan etablere imellem disse elementer (Foucault 1980b:194).

Det franske begreb dispositif oversættes som oftest til apparatus, disposition eller gruppering (Mahon 1982:120-1). Dreyfuss og Rabinow vælger betydningsnet (grid of intelligibility) (1982:120 ff.) i deres fremstilling, og jeg anser denne oversættelse som mest rammende. Med dispositiv-begrebet forsøger Foucault netop at isolere det betydningskompleks eller den logik, der er ansporende drivkraft for forskellige praksisser. Formålet med en „dispositionel analyse“ er følgelig at lokalisere og forstå dette betydningsnet, der organiserer den sociale virkelighed, uden at man analytisk henviser til et konstituerende subjekt eller objektive love (op.cit.:121). Det kan således hævdes, at dispositivet virker som en social „understrøm“, der på tværs af utallige heterogene kontekster sammenbinder enkelte hændelser (Raffnsøe 2000:65). Dispositivet er således sammensat af linjer, der konstant tvedeles og forskydes i et uens netværk (Deleuze 1992:159). Dispositivet er dét, der for en stund lader disse linjer berøre hinanden. Egentlig er det ingenting, og alligevel påvirker det den måde, vi forholder os til hinanden på.

\section{Dispositivets funktion}

I takt med sin tilblivelse udfylder dispositivet en overordnet funktion, som det i løbet af sin konstitutionshistorie er med til at udvælge og udforme (Raffnsøe 2000:64). Det har altså en strategisk funktion, der efterhånden kommer til at virke som dispositivets matrix ${ }^{4}$ (Foucault 1980b:195). Foucault beskriver blandt andet, hvordan den spirende industrialisme i Frankrig producerede et tvingende behov for at „fastspænde“ arbejderne i de tunge industrier til deres arbejdspladser. Dette skete gennem forskellige lokale taktikker: Man pressede folk til at gifte sig, tilbød boliger og forpligtede arbejderne ved at indføre forskellige kreditsystemer (Foucault 1980b:202 ff.). Gennem diverse institutioner blev disse eksperimenter generaliserede og dannede en sammenhængende logik, uden at der dog kunne identificeres en ophavsmand (Foucault 1998:101). Dispositivet er her den skrøbelige hinde, der temporært er dannet hen over magtens utallige mikrorelationer.

\section{Dispositivets ustabile foreskrivning af handling}

Således afdækker dispositivanalysen et foreskrivende niveau, der er blevet til gennem social interaktion, og som ingen derfor har skabt. Dispositivet virker altså som et filter for perceptionen, som et sæt af sociale tilbøjeligheder, der synes at bestemme, hvad der overhovedet kan lade sig gøre socialt set (Foucault 1991:81). Men det hævdes ikke, at 
der vil blive handlet i overensstemmelse med dispositivet, kun at nye retningslinjer har gjort sig gældende (Raffnsøe 2002:75). Den dispositionelle logik er aldrig almægtig. Den lever tværtimod af, at man konstant bryder op fra den, forskyder den og bevæger sig imod noget nyt (Deleuze 1992:163). I den dispositionelle analyse vil dispositivet derfor blive fremanalyseret som en idealfigur, der aldrig genfindes i sin pure form. I sin faktiske gestalt er dispositivet allestedsnærværende, som en foreskrivning af social udveksling, der bestandigt forskydes fra idealfiguren netop i kraft af de lokale handlinger, hvori dispositivet må virke for at sætte rudimentære spor.

\section{Dispositivets genealogi}

For at kunne fastslå karakteren af dispositivets logik er det nødvendigt at fokusere på de forgreningsøjeblikke eller begivenheder, der ændrer dispositivets retning. Raffnsøe definerer her begivenheden:

Såfremt en handling eller hændelse, der finder sted, lader sig anskue som en akt der gør en forskel, som udgør en forskel i forhold til det tidligere i en eller flere henseender, kan den karakteriseres som en begivenhed (Raffnsøe 2002:21).

Igennem analyse af disse allerede hændte begivenheder er det muligt at genopdage, hvordan det, der senere kom til at gælde som selvfølgelighed, blev etableret (Foucault 1991:76). Ethvert kulturelt eller socialt fænomen har altså en tilblivelseshistorie, man genealogisk må efterspore for at kunne konstruere dispositivets logik (op.cit.:77). Begivenhederne må stadfæstes ,,i deres særegenhed, på afstand af enhver monoton finalitet; de må opspores der, hvor man mindst venter dem, og i elementer som går for ikke at have nogen historie“ (Foucault 1984:76). Denne tanke har sin oprindelse i Nietzsches tankeunivers; og navnlig i hans genealogi over moralen (1999 [1887]). For Nietzsche er alle værdier skabt på baggrund af en viljeshandling ud fra et specifikt perspektiv. „Alt, der nu har værdi i vores verden, har ikke værdi i sig selv, ifølge sin natur - naturen er altid værdifri, men er blevet givet værdi på et tidspunkt [...] - og det var os, der gav og skænkede den“ (Nietzsche 1974 [1882]:301 i Mahon 1992:83; min oversættelse).

Der findes intet skabende $\varnothing$ jeblik for de kulturelle og sociale fænomener, der udgør vores omverden (Foucault 1984:77). Søger vi tilbage til tingenes oprindelse, finder vi kun viljesbestemte fortolkninger og derunder intet (Mahon 1992:83). Vi må således konstatere, at de værdier og selvfølgeligheder, vi omgives af, er skabt i kampe mellem stridende magtviljer, der hver især fortolker ud fra egne målsætninger (Foucault 1984:79). Disse konstateringer er uomgængelige for en dispositionel analyse, da det hermed klarlægges, at det er igennem kontingente begivenheder, at historien skrider frem (Foucault 1984:76). I en spidsformulering, er det begivenhederne, der gør os til dét, vi er. De viljeshandlinger, der på ethvert tidspunkt skaber værdierne, fortsætter imidlertid deres virke, således at tidligere begivenheder genfortolkes og indsættes i nye sammenhænge, der slører deres tilblivelseshistorie (Nietzsche 1999 [1887]:80ff.). Det er på denne vis, at der opstår en tro på tingene, ,sådan som de er”. 


\section{Empirisk genlæsning: Deltagelsens dispositiv}

Med dispositivanalysen som optik var det muligt at aftvinge en anderledes læsning af mit empiriske materiale. Indledningsvist arbejdede jeg med to historiske dynamikker, der afløste hinanden, altså dyadiske patron-klient-forhold efterfulgt af folkelig deltagelse. Ud fra en sådan rigid opdeling kunne jeg ikke i tilstrækkelig grad redegøre for de problemer, bruddet imellem dem genererede. Jeg mente, det var åbenlyst, at der var ved at ske normative ændringer i hele den måde, hvorpå mine informanter forholdt sig politisk til deres omverden. Disse var blot ikke entydige, men vekslende og i konstant forhandling. Det undrede mig, at ikke alle omfavnede idéen om folkelig deltagelse. Hélio, en af Miliagres' politiske ledere, opsummerer denne skepsis:

Hélio: Under kampagnen forsikrede han ['Orçamento Participativo's koordinator] om at folket skulle bestemme, og nu siger han, at hvis de [kommunen] får mulighederne, gør de det; hvis ikke, venter de, indtil mulighederne opstår. I det øjeblik blev det klart, at dette ikke er et styre for folket. De gør det, når de kan [...] det er ikke anderledes end det tidligere styre.

Jeg: Hvorfor skabte de så 'Orçamento Participativo', hvis det reelt ingenting ændrer?

Hélio: For at narre folket, for at kunne sige, at folket er med dem.

Dispositivanalysen fastslår, at de selvfølgeligheder, vi omgives af, har en konstitutionshistorie, der kan yde værdifuld information om den dispositionelle logik, der præger enhver samtid. Det blev mig således klart, at den åbenlyse selvfølgelighed, jeg var nødt til at efterspore, var den, der aftegnede et nyt og afgørende normativt handlerum i den kontekst, jeg studerede, nemlig deltagelse. Jeg var overbevist om, at den tvetydighed, dette fænomen var omgærdet af, måtte finde sin forklaring i dets tilblivelseshistorie. I sidste instans var det min hensigt at afdække et deltagelsens dispositiv .

Deltagelse indskrev sig i alternative udviklingsdiskurser i 1960'erne og blev anerkendt som uadskillelig fra officielle udviklingsprogrammer i det følgende årti (Woost 1997:231). Det blev hurtigt ,den manglende bestanddel“ i udviklingsprogrammer, der hidtil havde fejlet i løsningen af grundlæggende problemer om fattigdom og overlevelse (Stiefel \& Wolfe 1994:26, 221). Ved at inkorporere modtagerne i bistandsprojekterne ville sidstnævnte utvivlsomt virke på en mere konstruktiv måde.

Deltagelsens lokale tilblivelseshistorie i Brasilien udgøres af et sammenvævet net af overlappende, sideløbende og modsatrettede elementer, hvoraf jeg her kun skal behandle de væsentligste. Igennem de sidste tre årtier har Brasilien genneml øbet flere $\varnothing$ konomiske kriser igangsat af den anden oliekrise, $\varnothing$ gede internationale renter og fald i kommercielle låntagninger (Cornia et al. 1987:107). Denne situation startede en stadig igangværende proces med tilpasningsprogrammer, indledningsvis med IMF (International Monetary Fund). Dette har resulteret i en restrukturering af landets økonomi, såsom administrativ decentralisering, privatisering og restriktion af den offentlige sektor (Stiefel \& Wolfe 1994:197, 211).

I slutningen af 1980'erne var låneinstitutionerne presset til at anerkende, at tilpasning var uholdbar uden opmærksomhed på de sociale dimensioner (ibid.). Denne ændrede holdning skabte imidlertid et paradoks: Intentionen var at forøge den sociale st $\varnothing t t e$, samtidig med at udgifterne skulle reduceres; altså to modsatrettede strategier. Paradokset blev løst gennem en ny politik kaldet targeting, altså målrettet fokus på de grupper, 
der er mest i nød og som derfor vil drage størst fordel af bistand. For at realisere denne targeting, var det afgørende, at målgrupperne selv definerede deres behov; de skulle således deltage.

Den ny retorik tilsvares dog ikke af de realiteter, som den fors $\varnothing$ ger at skildre. Identifikation af potentielle støtteområder involverer som regel konsultation med de primære aktører (Tussie \& Tuozzo 2000:9). Formgivningen af projektet udføres imidlertid udelukkende af regeringen og låneinstitutionen. Ngo'er anses ydermere som stedfortrædere for civilsamfundet med det til følge, at de egentlige målgrupper siddes overhørige (Nelson 2000:417). Man kan derfor hævde, at deltagelse reelt hensættes til en sekundær rolle som ren overfladelegitimering.

Det betydningsfelt, som deltagelse dækker over, er præget af flere overlappende ra-tionaliteter, hvilket i den nuværende situation genererer de paradoksale holdninger over for fænomenet. Betragtes dette felt med dispositivanalysens optik, kan vi nærme os en forståelse af denne kompleksitet. Dispositivet udgøres af heterogene elementer, der bestandigt forskydes i forhold til hinanden (Foucault 1980b:194 ff.). En diskurs, der på et tidspunkt figurerer som et institutionelt program, kan efterfølgende tjene som maskering for det, der selv forholder sig tavs. Dette skete med loven, der indledningsvis fungerede som det overgribende dispositiv, for senere at blive underlagt disciplinens mere fordækte virke (Foucault 1980a:95 ff.). Således indflettes dispositiver i hinandens genstandsfelt, hvorved de lige så gerne kan tjene som organ for andre dispositionelle logikker, som de kan spille rollen som det beherskende (Raffnsøe 2002:105).

I den brasilianske kontekst kan vi registrere samme dynamik. Som ,importvare“ har deltagelse tjent som et nødvendigt slogan for at dæmpe kritikken imod strukturtilpasning. Sideløbende har de samme udviklingsdiskurser, der indledningsvis pressede de internationale låneinstitutioner til at inkorporere deltagelse i deres programmer, fortsat med at betone nødvendigheden af reelle participatoriske projekter. Samme krav er fremkommet fra brasiliansk side begyndende med den sociale mobilisering i diktaturets sidste fase, der ledte op til etableringen af PT og siden hen „Orçamento Participativo“. Tendenserne genfindes i Recife, hvor etableringen af PREZEIS er et genspejl af denne bredere udvikling. Forsimplet kan vi opstille to læsninger af deltagelse: Tilpasningsprogrammerne har produceret, hvad Sarah White kalder ,nominel deltagelse“ (1996:8). Dette viser, at regeringen ,gør noget“, og at den har en folkelig basis. Her tjener deltagelse primært som legitimering. Modsat manifesterer „Orçamento Participativo“ og PREZEIS en „transformativ deltagelse“ (ibid.). Idéen er „empowerment“ som direkte involvering i beslutningsprocessen. Det ses som regel som en dagsorden, der styres nedefra, hvor eksterne aktører kan støtte, men ikke skabe processen. Med „empowerment“ er deltagelse både midlet og målet.

\section{En begivenhed}

Jeg skal her kort skildre en begivenhed, hvor de to nævnte dispositionelle logikker løb sammen. Derved synliggør jeg, hvordan dispositivets mikrotransformationer virker i praksis.

På et møde i PREZEIS blev projektet Habitar-BID præsenteret for samtlige favela-ledere, ngo-arbejdere og kommunalt ansatte under PREZEIS. Habitar-BID var baseret på 
låntagning igennem IDB (Inter-American Development Bank), der virker som låne-institution for Latinamerika og det caraibiske øhav. Formålet med Habitar-BID var at „højne levestandarden for dem, der lever i 'subnormale' bosættelser“" og ,stimulere kommunale styreformer" (SEDU 2000:3). Projektet blev skabt af IDB og skulle foregå gennem en participatorisk praksis ud fra deres definition af deltagelse, der begrænser sig til konsultation (Tussie \& Tuozzo 2000:9). Den praktiske intention, som det blev fremlagt på mødet, var at bygge huse i de særlige områder, der faldt ind under PREZEIS' regi, for et samlet beløb på 22 mio. reais (på daværende tidspunkt svarende til 77 mio. danske kroner). For at fastslå, hvilke områder der skulle fokuseres på, fastsatte en arbejdsgruppe bestående af ngo-arbejdere og PREZEIS' koordinationsgruppe en række kriterier. Områderne med de bedste infrastrukturelle forhold ville blive tilgodeset først, givet at det ville lette implementeringen af projektet. Derudover vurderede man graden af fattigdom ud fra tre kategorier: fattig, meget fattig og kritisk. Nora, en kommunalarbejder, præsenterede kriterierne, som hurtigt blev godkendt gennem håndsoprækning. Bismarck, en favela-leder i PREZEIS' koordinationsgruppe, proklamerede så, at de valgte områder nu ville blive udråbt. På dette tidspunkt vidste ingen af deltagerne, at områderne allerede var blevet valgt. De havde udelukkende accepteret de kriterier, som arbejdsgruppen præsenterede dem for. Derfor lød der højlydte protester fra mange sider, men forgæves. Listen blev vist på en transparent efterfulgt af endnu mere larmende protester. João, en favela-leder i 30'erne, tog mikrofonen: „Jeg forstår ikke forskellen mellem fattig, meget fattig og ..." Bismarck afbrød ham: „Kritisk er, når du lever i slammet!“ Denne bemærkning antændte forsamlingen af favela-ledere, hvoraf mange af dem netop boede i den type områder, som Bismarck havde karakteriseret så lidet flatterende. Renato, en ngo-arbejder og deltager i PREZEIS' koordinationsgruppe, fors $\emptyset$ gte at forklare logikken bag vurderingen: „Jeg vil ikke fors $\varnothing$ ge at forsvare [vurderingerne]. Vi havde ikke tid til at lave vores egen undersøgelse, så vi brugte en undersøgelse lavet af universitetet til at definere kriterierne og bedømme områderne." Dette afsluttede præsentationen af Habitar-BID. Efter mødet fortsatte den opildnede diskussion. De fleste af lederne var stadig voldsomt frustrerede over ikke at have haft mulighed for at deltage i projektets udformning, men slog det hen som endnu et tegn på den generelle ignorante holdning, som de mente sig udsat for fra kommunens side. En måned efter dette møde blev et andet projekt præsenteret for samme gruppe. Dette projekt lignede Habitar-BID, men var finansieret af den føderale stat og således et egentlig internt projekt for PREZEIS. Det interessant er, at den participatoriske model fra Habitar-BID blev overført til dette projekt: Den samme arbejdsgruppe definerede både kriterier og områder, hvorved en håndsoprækning udgjorde det samlede participatoriske element.

Jeg analyserer denne korte række af handlinger som en begivenhed, der gør en forskel i forhold til det tidligere (Raffnsøe 2002:21). Da den participatoriske model fra Habitar-BID indkodes i det rationale, der underlægger PREZEIS, sker en betydningsforskydning i den dispositionelle logik, hvorved det, der virker selvindlysende, transformeres. Flere faktorer underst $\varnothing t t e r$ dette. Den rationalitet, der omkranser deltagelse set fra favela-lederne, sættes nu i forbindelse med kommunens manglende anerkendelse af deres position. Det participatoriske element lægges således ned over en praksis, der allerede fungerer, og som dermed bekræftes. For favela-lederne udtrykker deltagelse her den dominerendes hersken over den dominerede. Siden indsættes dette element i den logik, der forankrer PREZEIS, hvorved dette fundament undergår endnu en mikrotransformation, 
der genererer umærkelige, men dog reelle, normative ændringer. Spidsformuleret sker der en mutation i distinktionen mellem, hvad der gælder som rigtigt og forkert (Foucault 1991:82). Fremstår deltagelse som et element i en allerede eksisterende dynamik, der fortolkes negativt, vil en senere anerkendelse af samme praksis vise sig problematisk. Den normativitet, der introduceres med deltagelse, vil altså ikke nødvendigvis eliminere de patron-klient-forhold, der hidtil har præget det politiske landskab.

Det skal naturligvis understreges, at denne opdeling af forskellige overlappende logikker udelukkende er analytisk. For de implicerede aktører fremstår handlefeltet ikke så rigidt, som det måske er blevet fremskrevet. Her udgør deltagelse snarere en tvetydig, men dog reel social logik, man i stigende grad nødvendigvis må forholde sig til. De forskellige elementer, jeg her har skitseret, er således medskabere af denne komplekse virkelighed.

\section{For en kritisk antropologisk dispositiv-analyse}

I Marcel Mauss' hovedværk om udvekslingens moralitet, Gaven (2000 [1923-24]), beskrives det, hvordan den angivelige frie udveksling af gaver reelt forankres i forpligtelsesmekanismer, der etablerer nærmest uopløselige alliancer (op.cit.:39, 51). Det interessante for denne diskussion er Mauss' skildring af variationen og mulighederne immanent i udvekslingssystemerne. Det understreges, at den sociale samhørighed afhænger af stabile alliancer gennemstrømmet af gensidige forpligtelser. Imidlertid kan man aldrig være sikker på, at den forventede modydelse, hvormed de forpligtende bånd bestyrkes, reelt vil blive givet (op.cit.:44). Systemets faktiske realitet betinges således af aktørens handlinger. Disse velkendte teser tilsvares stort set af dispositiv-analysen, der stadfæster, at sociale bånd antager ,... netværkets overgribende og uomgængelige karakter“ som en „,... anden, 'menneskeskabt', natur“ (Raffnsøe 2002:17). Samtidig understreger dispositivanalysen imidlertid, at symbolske systemer afhænger af handlingens tilfældige karakter, der i ethvert $\varnothing$ jeblik forskubber de forankringspunkter, der tjener som kulturelle pejlemærker. Historiciteten bliver altså et ekstra parameter givet med dette teoriapparat. Samme historicitet diskuteres af Pierre Bourdieu i hans analyse af et nyt kabylsk ,sub-proletariat“ i Algeriet (1979). Bourdieu beskriver, hvordan objektive strukturer brat ændres, hvorved individers mentale strukturer, deres habitus, overhales af udviklingen. Bourdieu forholder sig således til historiciteten, men analyserer ikke indgående de mikroprocesser, hvorigennem transformationerne er foregået. Derved står man tilbage med en brudflade, der ikke redegøres for.

I en dispositionel optik gives der tværtimod en diakron tilblivelseshistorie, der opløser strukturens selvfølgelighed. Jeg har i nærværende artikel forsøgt at udvide analyseformen ved også at medtænke de begivenheder, der kan observeres her og nu. I sin oprindelige udlægning er det udelukkende de historiske og således fortidige hændelser, der fokuseres på. Dette udgangspunkt må revideres, hvis analyseformen skal bruges i et antropologisk arbejde. I det beskrevne eksempel har jeg netop fors $\emptyset \mathrm{gt}$ at indarbejde de observationer, jeg gjorde mig under mit feltarbejde, hvorved dispositivanalysens antropologiske relevans blev anskueliggjort.

Sluttelig skal jeg opsummere, hvorfor en dispositivanalyse er relevant for kritisk antropologisk arbejde. I en dispositionel optik må vi erkende, at vores samtid ikke er 
unik. Det er en tid som alle andre, men som derved også adskiller sig fra alle andre gen-nem stadige mikrotransformationer. Ved at opstille genealogier sættes samtidens selv-følgeligheder i bevægelse. Når de angiveligt grundlæggende værdier pludselig viser sig at forankres i kontingente menneskelige handlinger, bliver det klart, at det, der er, ikke behøver at være (Foucault 1988a:36 f.). Som Nietzsche minder os om, er det kritik at betvivle værdierne, da det medfører en overvejelse over, om de reelt tjener eller hæmmer menneskets trivsel (Nietzsche 1999 [1887]:17). Denne kritik er imidlertid aldrig hævet over den kontekst, som den forsøger at indramme. Forskeren er i bund og grund involveret i og delvist produceret af de samme kulturelle praksisser, som han studerer (Flyvbjerg 1999:94). Derfor kan han ikke stå uden for det studerede, men må snarere tage udgangspunkt i sin holdning til, hvordan tingenes tilstand er i det samfund, han arbejder i. Foucault fastslår, at man bør starte med et problem, der udtrykkes i nutidens termer, hvorefter dets genealogi udarbejdes (Foucault 1988b:262). I mit tilfælde blev spørgs-målene: Hvad har bevirket, at fænomenet deltagelse er opstået, som i dag melder sig for os med krav om gyldighed? Hvilke omkostninger har dette for de implicerede aktører, og hvordan påvirker denne rationalitet aktørernes virkefelt? Forskerens holdning kan imidlertid ikke udspringe af rene idiosynkratiske præferencer, hvorfor den må baseres på opfattelser i den gruppe, der studeres. Her vil det imidlertid være klart, at der ikke gives én moral, men et spraglet univers af moraliteter (Howell 1997:4). Deres indbyrdes dynamik og tilblivelseshistorie er det antropologens rolle at redegøre for.

Foucaults værk fremstilles ofte som opdelt i flere usammenhængende faser (Dreyfuss \& Rabinow 1982; Heede 1992). Med den sene introduktion af dispositiv-begrebet må denne opfattelse revurderes. Det er muligt at genlæse hans skrifter som løbende dispositiv-analyser, der med forskellige afsæt spidder vores samtid gennem opløsning af vore selvfølgeligheder. Det er min opfattelse, at disse analyser er af afgørende betydning ikke bare for kritisk antropologi, men for kritisk samfundsvidenskab generelt. Med dispositivanalysen gives et kritisk mellemniveau mellem teorien og den rene empiri, der bestandig repositionerer begge. Den hjælper os til at orientere os i ethvert flygtigt nu ved at forholde dette til sin forhistorie, der således får en betydelig rolle at spille. I denne analyseform indarbejdes nutidige og fortidige begivenheder i en udpegning af en fremtid, der forekommer stadig mere åben.

\section{Noter}

1. Jeg kan henvise den vantro læser til mit speciale „Contesting the Moralities of Leadership“ (2002) for en bredere diskussion af politisk lederskab i en brasiliansk favela, der inkorporerer den præsenterede teoriramme.

2. PREZEIS står for Plano de Regularização das Zonas Especiais de Interesse Social (Plan for regulering af de særlige områder der har social interesse).

3. Zonas Especiais de Interesse Social (særlige områder af social interesse).

4. Nick Crossley bemærker i denne sammenhæng ganske rigtigt, at dispositivet er det svar, der fremkommer ved at spørge til, hvordan magt virker (Crossley 1994:107). 


\section{Litteratur}

Abers, Rebecca

2000 Inventing Local Democracy. Grassroots Politics in Brazil. Boulder: Lynne Rienner Publishers.

Assies, Willem

1991 To Get out of the Mud. Neighborhood Associativism in Recife, 1964-1988.

Amsterdam: CEDLA.

Bourdieu, Pierre

1979 Algeria, 1960. Cambridge: Cambridge University Press.

Cornia, Giovanni Andrea, Richard Jolly \& Frances Stewart (eds.)

1987 Adjustment with a Human Face. Vol. 1. Oxford: Clarendon Press.

Crossley, Nick

1994 The Politics of Subjectivity. Aldershot: Avebury.

Deleuze, Gilles

1992 What is a Dispositif? Michel Foucault Philosopher. New York: Harvester Wheatsheaf.

Derrida, Jacques

1978 Writing and Difference. London: Routledge.

Doyal, Len \& Ian Gough

1991 A Theory of Human Need. New York: Guilford Press.

Dreyfuss, Hubert L. \& Paul Rabinow

1982 Michel Foucault. Beyond Structuralism and Hermeneutics. Chicago: The University of Chicago Press.

FASE

1997 PREZEIS. Plano de regularização das zones especiais de interesse social. Manual para Lideranças. Recife: FASE.

Flyvbjerg, Bent

1999 Rationalitet og magt. Det konkretes videnskab. Bind 1. København: Akademisk Forlag.

Foucault, Michel

1980a Two Lectures. I: Colin Gordon (ed.): Power/Knowledge: Selected Interviews and Other Writings 1972-1977. New York: Pantheon Books.

1980b The Confession of the Flesh. I: Colin Gordon (ed.): Power/Knowledge: Selected Interviews and Other Writings 1972-1977. New York: Pantheon Books.

1984 Nietzsche, Genealogy, History. I: Paul Rabinow (ed.): The Foucault Reader. London: Penguin Books.

1988a Critical Theory/Intellectual History. I: D.L. Kritzman (ed.) Michel Foucault, Politics, Philosophy, Culture. London: Routledge.

1988b The Concern for Truth. I: D.L. Kritzman (ed.): Michel Foucault, Politics, Philosophy, Culture. London: Routledge.

1991 Questions of Method. I: G. Burchell, C. Gordon \& P. Miller (eds): The Foucault Effect. Studies in Governmentality. Chicago: The University of Chicago Press.

1998 Viljen til viden. København: Det lille forlag.

Heede, Dag 1992

Det tomme menneske - Introduktion til Michel Foucault. København: Museum Tusculanums Forlag.

Holston, James

1991 The Misrule of Law: Land and Usurpation in Brazil. Comparative Studies in Society and History 33(4):695-725. 
Howell, Signe (ed.)

1997 The Ethnography of Moralities. London: Routledge.

Huchzermeyer, Marie

2002 Informal Settlements. Production and Intervention in Twentieth-Century Brazil and South Africa. Latin American Perspectives 122(29):83-105.

Laclau, Ernesto \& Chantal Mouffe

1985 Hegemony and Socialist Strategy. Towards a Radical Democratic Politics. London: Verso.

Liep, John

1999 Markedet i vores hoveder. Tidsskriftet Antropologi 40:59-68.

Mahon, Michael

1992 Foucault's Nietzschean Genealogy. Truth, Power, and the Subject. Albany: State University of New York Press.

Marcus, George

1998 Ethnography in/of the World System. The Emergence of Multi-Sited Ethnography. I: G.

Marcus: Ethnography through Thick and Thin. Princeton: Princeton University Press.

2002 Kritik og krise. Interview med George Marcus. Tidsskriftet Antropologi 44:5-14.

Mauss, Marcel

2000[1923-24] Gaven. Gaveudvekslingens form og logik i arkaiske samfund. København: Spektrum.

Nelson, Paul

2000

Whose Civil Society? Whose Governance? Decisionmaking and Practice in the New Agenda at the Inter-American Development Bank and the World Bank. Global Governance 6.

Nielsen, Morten

2002 Contesting the Moralities of Leadership. Specialeafhandling. København: Institut for Antropologi, Københavns Universitet.

Nietzsche, Friedrich

1887 [1999] Moralens oprindelse. København: Det lille forlag.

Raffnsøe, Sverre

2000 Michel Foucaults dispositionelle magtanalytik. Grus 20(59):45-70.

2001 Moralens evindelige genkomst. Introduktion til Nietzsches „Moralens Oprindelse“. København: Gyldendal.

2002 Sameksistens uden common sense - en elliptisk arabesk. København: Akademisk Forlag.

SEDU

$2000 \quad$ Programa Habitar Brasil BID. Regulamento Operacional.

Shields, Rob

$1991 \quad$ Places on the Margin. London: Routledge.

Souza, Flávio A.M. de

2001 The Future of Informal Settlements: Lessons on the Legalization of Disputed Urban land in Recife, Brazil. Geoforum 32:483-92.

Stiefel, Matthias \& Marshall Wolfe

$1994 \quad$ A Voice for the Excluded. Popular Participation in Development: Utopia or Necessity? London: Zed Books.

Tamboukou, Maria

1997 Writing Genealogies: An Exploration of Foucault's Suggestion for Doing Research. Ph.D.

Thesis. London: King's College.

Tussie, Diana \& María Fernanda Tuozzo

$2000 \quad$ Multilateral Development Banks and Civil Society Participation in Latin America. Paper præsenteret ved LASA 2000, Latin American Studies Association, XXII International Congress, Miami, Florida. 16.-18. marts. 
Vianna Jr., Aurelio

2000 Civil Society Participation in World Bank and Inter-American Development Bank Programs: The Case of Brazil. Global Governance 6:457-72.

UNRISD

2002

Social Safety Nets and Adjustment in Developing Countries. <www.unrisd.org/engindex/ publ/list/op/op1/op01-01.htm> (downloaded 16.04.02).

Wampler, Brian

2000

Participatory Publics and the Executive: Participatory Budgeting. Paper præsenteret ved

LASA 2000, Latin American Studies Association, XXII International Congress, Miami,

Florida. 16.-18. marts.

White, Sarah C.

1996 Depoliticising Development: The Uses and Abuses of Participation. Development in Practice 6(1):6-15.

Woost, Michael D.

1997

Alternative Vocabularies of Development? "Community" and "Participation" in

Development Discourse in Sri Lanka. I: R.D. Grillo \& R.L. Stirrat (eds): Discourses of Development. Oxford: Berg. 